\title{
Framing Organized Crime and Entrepreneurs' Reactions in Mexico Variations in the International Press
}

\author{
Ramirez, Jacobo; Muñiz, Carlos
}

Document Version

Accepted author manuscript

Published in:

Trends in Organized Crime

DOI:

10.1007/s12117-016-9271-6

Publication date:

2018

License

Unspecified

Citation for published version (APA):

Ramirez, J., \& Muñiz, C. (2018). Framing Organized Crime and Entrepreneurs' Reactions in Mexico: Variations in the International Press. Trends in Organized Crime, 21(1), 24-41. https://doi.org/10.1007/s12117-016-9271-6

Link to publication in CBS Research Portal

\section{General rights}

Copyright and moral rights for the publications made accessible in the public portal are retained by the authors and/or other copyright owners and it is a condition of accessing publications that users recognise and abide by the legal requirements associated with these rights.

Take down policy

If you believe that this document breaches copyright please contact us (research.lib@cbs.dk) providing details, and we will remove access to the work immediately and investigate your claim. 


\title{
Framing Organized Crime and Entrepreneurs' Reactions in Mexico: Variations in the International Press
}

\section{Jacobo Ramirez and Carlos Muñiz}

\author{
Journal article (Post print version)
}

This article was originally published in Trends in Organized Crime.

First published online: March 10, २016.

The final publication is available at Springer via http://dx.doi.org/10.1007/s12117-

016-9271-6.

Uploaded to Research@CBS: April २०16 


\title{
Framing organized crime and entrepreneurs' reactions in Mexico:
}

\section{Variations in the International Press}

\author{
Dr. Jacobo Ramirez \\ Assistant Professor \\ Copenhagen Business School, Department of Intercultural Communication \\ and Management \\ Porcelaenshaven 18A 1.155 \\ Frederiksberg, Denmark, DK 2000 \\ e-mail: jra.ikl@cbs.dk \\ Dr. Carlos Muñiz \\ Professor \\ Universidad Autónoma de Nuevo León, Faculty of Political Science and \\ Public Administration \\ Edificio de Posgrado, Tercer Piso \\ Col. Residencial Las Torres 4 \\ Monterrey, Nuevo Leon, Mexico 64930 \\ e-mail: carlos.munizm@uanl.mx
}

Correspondence concerning this article should be addressed to Dr. Jacobo Ramirez

Conflict of Interest: Jacobo Ramirez has received research grants from the Department of Department of Intercultural Communication and Management (ICM) at Copenhagen Business School (CBS) under grant ICM HoDD and was co-sponsored by CBS' Competitive Platform. Author Carlos Muñiz received research grant from the Policy Communication Laboratory at the Faculty of Political Science and Public Administration at Universidad Autónoma de Nuevo León. Jacobo Ramirez declares that he has no conflict of interest. Carlos Muñiz declares that he has no conflict of interest. 


\title{
Framing organized crime and entrepreneurs' reactions in Mexico: Variations in the International Press
}

\begin{abstract}
This paper presents a quantitative content analysis (QCA) of international news that aims to identify and analyze the themes covered by the international press in relation to organized crime and violence in Mexico and to explore entrepreneurs' reactions to the covered news. We also analyze journalists' treatment of this news and the differences among international newspapers' coverage. Our results show that US and EU newspapers present more news related to violence toward entrepreneurs than do Mexican outlets, which tend to adopt an avoidance strategy. The conflict frame is more widely used in EU newspapers than in US and Mexican newspapers, whereas the economic frame is more common in US and Mexican newspapers than in EU newspapers. In addition, the morality frame is more frequently used by Mexican journalists than by US and European journalists. These results highlight the effects of framing in complex institutional contexts such as the Mexican context.
\end{abstract}

Keywords: Framing, media effects, organized crime, violence, entrepreneurs and social conflicts 


\section{INTRODUCTION}

The stories presented in the media can play an important role in capturing the dynamics between social groups and institutional environments (Scott 2013). Joutsenvirta and Vaara (2009: 89) suggest that news stories that explore societal contradictions and changes are significant to readers because of the particular frame used (Entman 1993).

In this paper, we present a quantitative content analysis (QCA) of news stories to analyze the issues covered by the press in relation to organized crime and violence in Mexico. We explore how the press presents the actions of entrepreneurs (owners of small and medium-sized enterprises (SMEs)) in response to violence. We also analyze journalists' coverage of this issue and the differences among coverage in newspapers originating from the US, Mexico, and the EU. These countries and regions are closely linked through cooperation and trade agreements, such as the North American Free Trade Agreement (NAFTA) between Mexico, the US, and Canada and the Economic Partnership, Political Coordination and Cooperation Agreement (the Global Agreement) between Mexico and the EU. 
We focus on entrepreneurs' responses to organized crime and violence. Entrepreneurs constitute a relevant focal group because, in fragile institutional contexts (Parker 2009), such as that in Mexico, they are confronted with corruption (e.g., Morris 2013), drug-trafficking organizations (DTOs), and other challenges. Furthermore, these entrepreneurs cannot rely on secure property rights enshrined in the rule of law and usually lack bargaining power (Parker 2009: 20) in the face of powerful drug cartels and public bureaucracy (Estrin and Prevezer 2011). Thus, the framing of news stories might establish a set of parameters (Semetko and Valkenburg 2000) that "influence... a human consciousness" (Entman 1993: 51) and "in which citizens discuss public events" (Tuchman 1978, p. IV). First, we present the theoretical background for our study. We then introduce the QCA methodology and our results to draw out implications for politicians, entrepreneurs, and academics.

\section{Issue framing in the media}

According to Entman (1993: 52), to frame "is to select some aspects of a perceived of reality and make them more salient in communication text." Arguably, members of civil society might construct their interpretations of organized crime and violence and their resulting actions based on journalists' 
framing of the situation. Along these lines, Neuman et al. argue that the frames used in news stories are "conceptual tools which media and individuals rely on to convey, interpret and evaluate information" (1992: 60). These authors identify five frames used in media coverage: economic, conflict, powerless, human impact, and morality frames. In this paper, we aim to explore the themes covered by the international media to analyze framing in the unique context of organized crime and violence in Mexico. To do so, we focus on the economic, morality, and conflict frames.

International news coverage of the "drug war" in Mexico has often highlighted negative aspects of the institutional context (Scott 2013). Some parts of Mexico are what O'Donnell (1999: 30) refers to as "brown" areasterritories characterized by "low-intensity citizenship" and the "un-rule of law." For example, reports covering organized crime and violence in the Mexican media tend to emphasize kidnapping, extortion, and physical violence, which affect civil society and/or infrastructure (e.g., Shirk 2010). The national and international press has used economic, morality, and conflict frames when covering these actions. 
The economic frame "reflects the preoccupation with 'the bottom line,' profit and loss" (Neuman et al. 1992: 63), particularly in terms of consequences for individuals, group, institutions, regions, or focal countries (Semetko and Valkenburg 2000: 96). Correa-Cabrera (2012: 214) argues that news stories presented in the US-Mexico border states of Texas and Tamaulipas frame the "negative effects of violence and U.S. border security policies on Mexico's economic progress and political stability [which] would also eventually affect the U.S.” Kim et al. (2011) find that US newspapers and television coverage mention the negative consequences of crimes committed by illegal immigrants. The mass media have depicted illegal immigrants as affecting the economy and have thus influenced public opinion on immigration policies (e.g., Citrin et al. 1997).

The morality frame situates an event, problem, or issue in the context of religious tenets or moral prescriptions (Semetko and Valkenburg 2000: 96). For example, Lacasse and Forster (2012) find that newspapers published near the US-Mexico border tend to adopt a more peace-oriented framework instead of a war-oriented framework. In their sample, newspapers that are geographically distant to the conflict use these two frames to approximately the same extent. 
The conflict frame emphasizes conflict among individuals, groups, or institutions (Semetko and Valkenburg 2000: 95) as a means of attracting attention. For example, Eversman (2013) finds two incompatible streams of discourse between harm reduction and "drug war" strategies in US newspaper media reports. Eversman finds this discrepancy, in particular, with regard to "how opponents and supporters framed the nature of drug use, addiction, and recovery, assertions that serve as the bedrock of their arguments" (2013: 17). In another line of research, Johnson et al. (2009) find that pre-election coverage in the US in 2006 adopted a substantive frame that defined elections in Latin American countries as "problematic" for US-Latin American relations (Johnson et al. 2009: 13).

News reports related to "brown areas" in Mexico appear to be presented in an "easy-to-understand interpretive package" (Kim et al. 2011: 293) to make the story more noticeable or memorable to audiences (Entman 1993). In this context, Pan and Kosicki (1993: 57) argue that "framing may be studied as a strategy of constructing and processing news discourse or as a characteristic of the discourse itself." The effects of framing are evident as "changes in judgment engendered by subtle alterations in the definition of judgment or choice of problems" (Iyengar 1987: 816). In the Mexican context, frames 
enable journalists to process the "war against cartels" and to "package the information for efficient relay to their audiences" (Gitlin 2003: 7). Therefore, one might argue that media reports on the war against drug cartels in Mexico have affected business development and civil society in many ways. For example, American and European firms have either delayed or cancelled plans to undertake foreign direct investment (FDI) in Mexico because of the prevalence of organized violence in the country (e.g., American Chamber of Commerce of Mexico, 2010). On the civil society level, the "new" wave of upper-class Mexican migration to the US and Canada has increased (Durin 2012).

The discussion above leads to our first two research questions:

RQ1: What frames are used by the press when covering violent actions?

RQ2: Does the use of frames vary significantly among the international press?

\section{Responses to institutional pressures}

Entrepreneurs find contexts with organized crime to be challenging because they cannot rely on property rights enshrined in the rule of law, and 
they usually lack bargaining power with powerful organized crime cartels (Parker 2009: 20) and public bureaucracies (Estrin and Prevezer, 2011), which, as suggested in the Mexican case, are steeped in endemic corruption (Morris 2013). Morris (2013) argues that organized crime cannot operate without some form of corruption; in the context of this research, violent corruption is defined as the use of violence to induce the acceptance of bribes or other activity (Dulin and Patiño 2014). In contexts encompassing organized crime and violent acts, entrepreneurs might consciously or unconsciously devise different methods to respond to institutional pressures, such as pressures stemming from governments and drug cartels (Morris 2013). Oliver (1991) proposes a model that encompasses several strategic responses to institutional pressures: acquiescence, avoidance, defiance, and manipulation. "Acquiescence" refers to acceding to institutional pressures (Oliver 1991), such as complying with illegitimate demands. Acquiescence can take several forms: 1) habit, which refers to unconscious or blind adherence to preconscious or taken-for-granted value rules (Oliver 1991); 2) imitation or voluntary, conscious avoidance; and 3) compliance. In this research, we refer to extortion or cuotas (payoffs), which are the illegitimate financial demands that organized crime imposes on entrepreneurs. Morris (2013: 206) classifies 
different forms of payoffs: money given to public officials (e.g., for physical protection) or favors to public officials (e.g., to avoid persecution) and societal actors, such as bankers (e.g., money laundering), journalists (e.g., positive coverage by choosing to not report certain stories), and members of cartels (e.g., false testimony)

"Avoidance" is an organizational attempt to preclude the necessity of conforming by concealing, buffering, or escaping institutional pressures. Concealment is nonconformity hidden behind a façade of acquiescence that is purely symbolic (Pache and Santos 2010: 462). Buffering refers to an organization's attempt to reduce the extent to which it is externally scrutinized by partially detaching or decoupling its technical activities from external contacts (Oliver 1991: 155), perhaps by restricting the distribution of information (Hirschman 1970). Escape refers to an organization's exit from the domain in which pressure is being exerted (Hirschman 1970) or to significant alterations in the organization's goals, activities, or domains to avoid the need to conform (Oliver 1991: 155).

"Defiance" is a more active form of resistance to institutional pressures (Oliver 1991) that includes dismissal, challenge, and attack tactics. Dismissal, 
which entails ignoring institutional rules and values, is a strategic option that entrepreneurs are more likely to exercise when the potential for external enforcement of institutional rules is perceived as low. Challenge tactics involve contesting the imposed norms, whereas attack tactics refer to an organization's intense and aggressive departure from institutional pressures and expectations (Oliver 1991).

"Manipulation" refers to the active intent to change or exert power over institutional pressures (Oliver 1991) through co-optation, influence, or control. A co-optation tactic seeks to neutralize institutional opposition and to enhance legitimacy. Influence and control are tactics that specifically seek to establish power and dominance over the external constituents that apply pressure to an organization (Oliver 1991). This tactic is related to Hirschman's (1970: 30) notion of voice as "any attempt at all to change, rather than to escape," which has also been referred as to alteration (Henrekson and Sanandaji 2011). In Oliver's (1991) repertoire, from a passive role, the institutional context is considered one in which entrepreneurs cannot make an impact: it is the way that society functions. However, some individuals might take a more proactive role in an effort to change the institutional context. 
This discussion leads us to the following research questions:

RQ3: What violent acts toward entrepreneurs are reported in the international press, and what are entrepreneurs' responses according to the press coverage?

RQ4: Does coverage vary significantly among the international press?

\section{METHODS}

To investigate our research questions, which focus on variations in the content found in the international press in relation to the coverage and framing of violence-related topics and entrepreneurs' responses, we conducted a QCA of international mass media reports on the situation in Mexico. The QCA was developed in several stages.

In the first stage, we searched the Factiva database for articles containing the following keywords: "SMEs," "entrepreneurs," "crime," "violence," "Mexico," "cartels," and "extortion." The search covered articles published between December 1, 2006, and November 30, 2012. This period corresponds with the presidency of Felipe Calderón Hinojosa, the Mexican president who implemented the "war against cartels" strategy. As the Factiva database does 
not include Mexican news outlets, we also conducted a manual search of news available on the websites of the most influential Mexican newspapers in terms of readership: La Jornada, Milenio, El Porvenir, CNNMéxico, La Prensa, and Proceso. This search yielded a total of 4,436 Mexican and international news reports.

In the second stage, we imported the 4,436 electronic documents into the NVivo10 qualitative software package. We analyzed the data set to identify articles that covered the hard facts (Joutsenvirta and Vaara 2009) related to our main research topic: organized crime and violence toward entrepreneurs and or SMEs. We searched for the keywords individually and in combination to develop an understanding of organized violence and crime as well as entrepreneurs' responses. This procedure narrowed the number of documents to 2,446. Of these stories, 673 mentioned at least one violent incident. Of those 673 articles, 204 presented at least one response from an entrepreneur. We used these 204 articles as the main data set. These articles included media reports that discussed actual violence and criminal acts (INEGI 2013), media reports that mentioned at least one entrepreneur's response to violence in Mexico (Oliver 1991; Sutter et al. 2013), and media reports that integrated statements made by entrepreneurs that illustrated their responses to violence. 
In the third stage, we hired two bilingual (Spanish-English) Ph.D. students in communications to independently code the 204 newspaper articles using a codebook. Although the coders were trained to use the codebook, neither the research questions nor the purpose of the research was revealed.

The codebook was constructed by integrating the economic, morality, and conflict framing categories from Semetko and Valkenburg's study (2000: 100). Strategic responses to institutional pressures were based on the work of Oliver (1991), as mentioned above. Data on violence and acts of crime were obtained from the Mexican national survey of victimization and perceptions of public safety (INEGI 2013). The documents were read in full to ensure a detailed and systematic analysis to uncover paragraphs that could be used to frame and assess entrepreneurs' responses to organized crime and violence. The inter-coder reliability-Cohen's kappa coefficient (Brennan and Prediger 1981)_for a random subsample of 50 media reports was between $81 \%$ and $100 \%$ for all variables. The lowest kappa coefficients were found for the attack tactic (81\%) and for escape within the current city (90\%). For the other tactics, the level of agreement between the two independent coders was $100 \%$. 


\section{RESULTS}

Of the 204 newspaper articles, $105(51.5 \%)$ originated in the US; 53 originated in Mexico (26\%); 29 originated in Spain (14.2\%); 7 originated in the United Kingdom (3.4\%); 6 originated in France (2.9\%); 3 originated in Canada (1.5\%); and 1 originated in New Zealand (.5\%). The average length of the sample stories was 701.28 words $(S D=1,144.80)$, and the article length ranged from 248 to 10,390 words. To assess the variety found in news reports, European newspapers were integrated into one subsample. Although each European country has different perspectives from which it presents news reports, our intent was to assess the reports by blocks of countries and regions. Thus, the final sample had the following number of newspaper articles: 105 for the US, 53 for Mexico, and 42 for the EU. Canada and New Zealand were not considered in the final sample because of the small number of newspaper articles originating from these countries.

Our first two research questions focus on the frames used to cover violent actions and on whether the use of frames varies significantly in the international press. All news reports were coded according to the frame typologies (Semetko and Valkenburg 2000: 100) to investigate whether the 
use of frames varied by country or region. We conducted a principal component analysis with varimax rotation of the framing typologies, and the results yielded three distinguishable factors (eigenvalues $>1$ ) that explained $70 \%$ of the total variance: conflict $(\alpha=.806)$, economic $(\alpha=.850)$, and morality $(\alpha=.678)$ factors. We then undertook a multivariate analysis of variance (MANOVA) based on the type of news frame (i.e., conflict, economic, and morality) and the country/region (US, Mexico, and the EU). The MANOVA showed a significant main effect between the independent variables $\left(\lambda\right.$ Wilks $\left.=.789, F(6,390)=8.158, p<.001, \eta^{2}=.112\right)$. This interaction suggests that the combinative effect of the three news frames is not the same in the US, Mexico, and the EU.

In addition, we conducted univariate analysis of variance (ANOVA) tests to analyze the main effect of the country/region (US, Mexico and the EU) on the three news frames. As shown in Table 1, the results for the use of the conflict frame are statistically significantly different $(F(2,197)=4.298, p<$ $\left..05, \eta^{2}=.042\right)$. In this regard, the Scheffé post hoc test reveals a difference between Mexico $(M=.08 ; S D=.24)$ and the US $(M=.23 ; S D=.33)$, which indicates that news reports originating from the US use the conflict frame more often than those originating from Mexico. However, the results do not 
show a statistically significant difference between the reports in the EU $(M=$ $.18 ; S D=.30)$ and Mexico or between those in the US and the EU.

A significant difference also exists for the economic frame $(F(6,390)=$ $8.994, \mathrm{p}<.001, \eta 2=.084)$ : the Scheffé post hoc test indicates that articles originating from the US $(M=.48 ; S D=.43)$ and Mexico $(M=.38 ; S D=.43)$ use this frame more than those originating from the $\mathrm{EU}(M=.16 ; S D=.32)$. Finally, we find a significant difference for the morality frame $(F(6,390)=$ $6.538, p<.01, \eta^{2}=.062$ ), as the Scheffé post-hoc test shows that reports originating from Mexico $(M=.32 ; S D=.36)$ use this frame more often than those originating from the US $(M=.15 ; S D=.24)$ or the EU $(M=.17 ; S D=$ $.31)$.

Insert Table 1 about here

Our last two research questions pertain to which violent acts toward entrepreneurs and which entrepreneurs' responses are reported in the international press and to whether this coverage varies significantly by country or region. First, we conducted a principal component analysis with varimax rotation to group 13 different types of violence and crime, termed 
"informed actions" in this paper, covered in the news: 1) kidnapping, 2) injury due to physical aggression, 3) murder, 4) robbery or assault (on the street or on public transport), 5) face-to-face threats, 6) face-to-face extortion at SMEs, 7) total or partial theft of SMEs' materials, 8) e-mail threats, 9) phone threats, 10) fraud or bank card cloning, 11) social media threats, 12) the destruction of SMEs' property, and 13) theft or assault at SMEs. The analysis resulted in two orthogonal factors (eigenvalues > 1) that explain $60 \%$ of the total variance.

Violence and SME infrastructure: The violent and criminal acts included in this factor are 1) face-to-face extortion at SMEs, 2) total or partial theft of SMEs' materials, 3) the destruction of SMEs' property, and (4) theft or assault at SMEs. This factor was named "violence and SME infrastructure" $(\alpha=$ $.704)$

Violence and entrepreneurs: The violent and criminal acts constituting this factor are 1) robbery or assault (on the street or on public transport), 2) injury due to physical aggression, 3) kidnapping, and 4) murder. This factor was termed "violence and entrepreneurs" $(\alpha=.747)$.

Second, to investigate the underlying strategic responses to institutional pressures, we developed a separate principal component analysis with 
varimax rotation covering the 12 different response tactics. The 12 tactics were clustered into three orthogonal factors (eigenvalues > 1) that explain $53 \%$ of the total variance: acquiesce $(\alpha=.817)$, avoid $(\alpha=.688)$, and manipulate $(\alpha=.831)$. The conceal and buffer tactics (avoidance strategies) and the dismiss, challenge, and attack tactics (defiance strategies) were not included in the analysis, as they did not meet the threshold (item loadings greater than .50). The avoidance factor is composed of three forms of escape that emerged from the QCA: 1) closing the SME, 2) escaping to another Mexican state, and 3) escaping to the US. The acquiesce and manipulate factors were clustered as suggested in the theoretical discussion.

Finally, to investigate whether reported violence and entrepreneurs' responses varied, we conducted a MANOVA with strategic responses (avoidance, acquiescence, and manipulation) and violent and criminal acts (violence and SME infrastructure and violence and entrepreneurs), using the countries/regions as the independent variables. We observed an interaction between the informed actions (violence and crime) reported in the news outlets and the country of origin or region. The multivariate $F$ statistics with a Wilks's lambda criterion indicate a global interaction among the independent variables $\left(\lambda\right.$ Wilks $\left.=.732, F(10,386)=8.158, \mathrm{p}<.001, \eta^{2}=.145\right)$. This result 
indicates that the US, Mexico, and the EU do not exhibit the same combinative effect of the independent variables on the reported violence and entrepreneurs' responses.

The results indicate the presence of a statistically significant difference for the avoidance strategy $\left(F(2,197)=8.744, p<.001, \eta^{2}=.082\right)$. The Scheffé post hoc test shows that Mexico's newspapers $(M=.23 ; S D=.36)$ adopt this strategy more than newspapers from the US $(M=.13 ; S D=.22)$ or the EU $(M$ $=.02 ; S D=.07)$. The differences between the US and the EU are not significant.

A statistically significant difference is found for the acquiescence strategy $\left(F(2,197)=5.747, p<.01, \eta^{2}=.055\right)$. The Scheffé post hoc test shows that newspapers in the EU region $(M=.37 ; S D=.38)$ adopt this strategy more often than newspapers in the US $(M=.16 ; S D=.32)$. However, no statistically significant difference exists between the EU and Mexico $(M=.22 ; S D=.37)$ or between the US and Mexico. Finally, the results do not show a statistically significant difference among the independent variables for the manipulation strategy $\left(F(2,197)=0.394, p=.675, \eta^{2}=.004\right)$. 
The results highlight a statistically significant difference for violence and SME infrastructure $(F(2,197)=3.293, p<.05, \eta 2=.032)$. The Scheffé post hoc test indicates that news reports originating from the EU region $(M=.26$; $S D=.28)$ more often report violence directed at SME infrastructures than those originating from Mexico do $(M=.24 ; S D=.31)$, but no significant difference exists in relation to reports originating from the US. Table 2 shows a statistically significant difference for violent and criminal informed actions and entrepreneurs' reactions $\left(F(2,197)=11.427, p<.001, \eta^{2}=.104\right)$. The Scheffé post hoc test suggests that newspapers in the EU $(M=.65 ; S D=.26)$ and in the US $(M=.67 ; S D=.34)$ report such actions more than those in Mexico do $(M=.41 ; S D=.37)$ (see Table 2 for details).

Insert Table 2 about here

\section{DISCUSSION}

This paper aimed to investigate the variation in the coverage of violent actions and response strategies in international newspapers. Four specific research questions were investigated. We studied the prevalence of violent actions (INEGI 2013), strategic responses to institutional pressures (Oliver 
1991), and the three framing typologies (Neuman et al. 1992; Semetko and Valkenburg 2000).

Overall, newspapers from the EU are more likely than those from Mexico or the US to report on violence affecting SME infrastructure and entrepreneurs and to use acquiescence and manipulation strategies (note that violence and entrepreneurs are more likely to be covered in the US than in Mexico). Although our study focused on SMEs and entrepreneurs, the higher number of news reports pertaining to these items in the EU might imply that journalists from Spain, the United Kingdom, and France are concerned with protecting European investments and civil society in Mexico. This concern could be related to the human rights clause included in the Global Agreement between Mexico and the EU (European Parliament 2005), which also seems to be a concern for US journalists. This informed action (violence and crime) appears to be relevant for international business, as the US and the EU are the two regions with substantial business relations with Mexico, frequently in the form of FDI and trade (U.S. Trade Representative, 2013; European Commission 2013). The coverage of informed actions in the media might also imply that although violence that affects infrastructure and entrepreneurs is considered typical of business in Mexico (the acquiescence strategy), civil 
society is demanding a response to this violence (the manipulation strategy). We interpret the evident manipulation strategy in the Mexican press as a trend in which the news media emphasize Mexican civil society's demands for an efficient response from local and federal governments to organized crime and violence in Mexico. These reported actions and strategic responses to the institutional constraints in Mexico led us to analyze framing effects in this study.

The predominance of the conflict frame in US media outlets suggests "polarized forces - the two sides of the issue" (Neuman et al. 1992: 64). In other words, this frame implies that there are winners and losers in the Mexican government's policy (2006-2012) on the "war against drug cartels." This policy seems to be supported by such actors as the US government, which introduced, for example, the Merida Initiative (Abu-Hamdeh 2011). The conflict frame fits well with the media's "game" interpretation (Neuman et al. 1992) of the political discourses on the fight against drug cartels in the US and Mexico. In this respect, journalists in the US and those in Mexico seem to adopt different perspectives when interpreting organized violence and crime in Mexico. For example, the news stories included in our study covered different polarized forces. The US articles emphasized topics related to the 
corruption of Mexican officials and the increased violence in the border states between the US and Mexico as a result of the drug cartels' operations in Mexico. By contrast, Mexican newspapers tended to emphasize the US government's efforts to fight its "drug war" in Mexico, drug consumption in the US, and other issues.

The economic frame was more likely to be used in news stories originating from the US and Mexico than in stories found in EU newspapers. The economic frame reflects the preoccupation with profit and loss and the values associated with the culture of capitalism (Neuman et al. 1992: 63). We deduce that the costs of the "war against drug cartels" and its economic consequences, such as the loss of entrepreneurs in Mexico, seem to be a common focal topic for journalists in Mexico and the US. The news stories in our sample tended to discuss the economic aspects of organized crime and violence in Mexico. Other news agencies emphasized the costs of the "war against drug cartels" for the US and Mexican governments. For example, USD 1.6 billion has been set aside for the Merida Initiative (U.S. Department of State 2013). Mexican newspapers, such as La Jornada and El Norte, frame news stories in relation to the costs of organized crime and violence for civil 
society. Typical topics include the economic costs of extortion payments (cuotas) or SME closures in Mexico.

The morality frame was particularly evident in the Mexican news, suggesting a social prescription for how to confront the conflict between legitimate and illegitimate institutional arrangements in Mexico. The findings suggest that members of civil society in fragile institutional contexts remain vulnerable (Parker 2009) to violence and crime (Sutter et al. 2013). Although institutional arrangements in Mexico are different, they are culturally and economically derived. As suggested by Neuman et al. (1992: 72), "none would dispute that cultural values are deeply embedded in modern journalistic practice." We interpret the tendency of Mexican news outlets to rely on morality framing as explaining why the increase in organized crime and violence in Mexico seems to be forcing civil society to adapt its modus operandi. We infer that different levels of civil society introduce alternatives that enable them to confront violence and crime by pressuring governmental officials to increase institutional efficiency. In general, the results presented here imply an ongoing process of social change in Mexican society, and this process is most evident among members of the middle class. 


\section{CONCLUSIONS}

Researchers argue that the framing of choices can have profound consequences for individual perceptions of risk (Semetko and Valkenburg 2000). The consequences of the informed actions (violence and crime) reported in the news and journalists' treatment of those stories can have important impacts. For example, framing might be considerably powerful in establishing the context for the debate on the "war against drug cartels" in Mexico by "defining issues, summoning a variety of mental representations, and providing the basic tools to discuss" (Pan and Kosicki 1993: 70) organized crime and violence. Thus, framing might influence how civil society and policymakers understand the effects of organized crime and violence in Mexico. For example, the pressure and demands for a more efficient strategy to fight drug cartels in Mexico, as reported in international newspapers, might have framing effects on public opinion.

In complex institutional settings, such as "brown areas" (O’Donnell 1999: 30), entrepreneurs seem to respond in certain ways to fulfill institutional gaps. The Mexican experience serves as a useful setting to discuss how framing affects institutional arrangements and challenges, which in turn play a key 
role in a country's growth potential. In fact, the Mexican experience maybe applicable to the Latin American region.

Additional studies building on our findings and integrating television news could further examine the effects of framing on entrepreneurs' responses to organized crime and violence in Mexico. This context also provides fertile ground for the development of new elements for framing effect studies. Additional research on emerging economies, particularly in Latin America, might help us to better understand how entrepreneurs respond to institutional constraints and enable us to examine how framing affects policymakers when designing strategies that reflect the institutional context.

Compliance with Ethical Standards: This work was supported by the Department of Department of Intercultural Communication and Management (ICM) at Copenhagen Business School (CBS) under grant ICM HoDD and was co-sponsored by CBS' Competitive Platform, and by the Policy Communication Laboratory at the Faculty of Political Science and Public Administration at Universidad Autónoma de Nuevo León.

Ethical approval: This article does not contain any studies with human participants or animals performed by any of the authors. 


\section{REFERENCES}

Abu-Hamdeh S (2011) The Merida initiative: an effective way of reducing violence in Mexico? Pepp Pol Rev 4:5

American Chamber of Commerce of Mexico 2010. Is Your Investment Safe?

- American Chamber of Commerce of Mexico

http://www.amcham.org.mx/wcwebcontent/webcontentpage.aspx?cont entid=11171. Accessed July 11, 2103.

Brennan RL, Prediger DJ (1981) Coefficient Kappa: some uses, misuses, and alternatives. Educational and Psychological Measurement 41:687-699. doi: $10.1177 / 001316448104100307$

Citrin J, Green DP, Muste C, et al. (1997) Public opinion toward immigration reform: the role of economic motivations. J Pol 59:858-881. doi: $10.2307 / 2998640$

Correa-Cabrera, G. (2012) The spectacle of drug violence: American public discourse, media, and border enforcement in the Texas-Tamaulipas border region during drug-war times. Norteamérica, 7(2), 199-220.

Dulin AL, Patiño J (2014) The logic of cartel car bombings in México. Trends Organized Crime 17:271-289. doi: 10.1007/s12117-014-9230-z 
Durin S (2012) Los que la guerradesplazó: familias del noreste de México en el exilio [the war that displaced: North Eastern Mexico families in exile]. Desacatos 38:29-42

Entman RM (1993) Framing: toward clarification of a fractured paradigm. J Commun 43:51-58. doi: 10.1111/j.1460-2466.1993.tb01304.x

Estrin S, Prevezer M (2011) The role of informal institutions in corporate governance: Brazil, Russia, India, and China compared. Asia Pac J Manag 28:41-67. doi: 10.1007/s10490-010-9229-1

European Commission (2013) Trade countries and region-Mexico. http://ec.europa.eu/trade/policy/countries-andregions/countries/mexico/. Accessed 15 June 2015.

European Parliament (2005) Human Rights and Democracy clauses in the EU's International agreements. Directorate General for External Policies of the Union. http://www.europarl.europa.eu/meetdocs/2004_2009/documents/nt/58 4/584520/584520en.pdf. Accessed 20 May 2015.

Eversman MH (2013) Harm reduction and illicit drugs in U.S. newspapers. J Drug Policy Anal 6. doi: 10.1515/jdpa-2012-0005 
Gitlin T (2003) The whole world is watching, mass media in the making and unmaking of the New left. University Presses of California, Columbia and Princeton, Berkeley, CA

Henrekson M, Sanandaji T (2011) The interaction of entrepreneurship and institutions. J Inst Econ 7:47-75. doi: 10.1017/S1744137410000342

Hirschman AO (1970) Exit, voice, and loyalty: responses to decline in firms, organizations, and states. Harvard University Press, Cambridge, MA

InstitutoNacional de Estadística y Geografía (INEGI) (2013) Encuestanacional de victimización y percepciónsobreseguridadpública (ENVIPE) [National survey of victimization and perceptions of public safety]. (No. 364.101). Mexican National Institute for Statistics and Geography. INEGI, Mexico

Iyengar S (1987) Television news and citizens' explanations of national affairs. Am Polit Sci Rev 81:815-831. doi: 10.2307/1962678

Johnson MA, Davis JL, Cronin S (2009) Mexican expatriates vote? Framing and agenda setting in US news coverage about Mexico. Mass Commun Soc 12:4-25 
Joutsenvirta M, Vaara E (2009) Discursive (de) legitimation of a contested Finnish greenfield investment project in Latin America. Scand $\mathbf{J}$ Manag 25:85-96. doi: 10.1016/j.scaman.2008.11.002

Kim S, Carvalho JP, Davis AG, et al. (2011) The view of the border: news framing of the definition, causes, and solutions to illegal immigration. Mass Commun Soc 14:292-314. doi: 10.1080/15205431003743679

Lacasse K, Forster L (2012) The war next door: peace journalism in US local and distant newspapers' coverage of Mexico. Media, War \& Conflict 5:223-237. doi: 10.1177/1750635212447907

Morris SD (2013) Drug trafficking, corruption, and violence in Mexico: mapping the linkages. Trends Organized Crime 16:195-220. doi: $10.1007 / \mathrm{s} 12117-013-9191-7$

Neuman WR, Juts MR, Crigler A, et al. (1992) Common knowledge. News and the construction of political meaning. The University of Chicago Press, Chicago

O’Donnell G (1999) Horizontal accountability in new democracies. The selfrestraining state: Power and accountability in new democracies. In: Schedler A, Diamond LJ, Plattner MF (eds) The self restraining state: 
Power and accountability in New democracies. Lynne Rienner Publishers, London, pp: 29-51

Oliver C (1991) Strategic responses to institutional processes. Acad Manag Rev 16:145-179. doi: 10.5465/AMR.1991.4279002

Pache A, Santos F (2010) When worlds collide: the internal dynamics of organizational responses to conflicting institutional demands. Acad Manag Rev 35:455-476. doi: 10.5465/AMR.2010.51142368

Pan Z, Kosicki G (1993) Framing analysis: An approach to news discourse. Pol Comm 10:55-75. doi: 10.1080/10584609.1993.9962963

Parker SC (2009) The economics of entrepreneurship. Cambridge University Press, Cambridge

Scott WR (2013) Institutions and organizations. Ideas, interests, and identities. Sage Publishing House, London

Semetko H, Valkenburg P (2000) Framing European politics: A content analysis of press and television news. J Commun 50:93-109. doi: 10.1111/j.1460-2466.2000.tb02843.x

Shirk DA (2010) Drug violence in Mexico: data and analysis from 20012009. Trends Organized Crime 13:167-174. doi: 10.1007/s12117-0109096-7 
Sutter CJ, Webb JW, Kistruck GM, et al. (2013) 'Entrepreneurs' responses to semi-formal illegitimate institutional arrangements. J Bus Venturing 28:743-758 doi: 10.1016/j.jbusvent.2013.03.001

Tuchman G (1978) Making news: A study in the construction of reality. The Free Press, New York

U.S. Department of State (2013) Merida initiative.

http://www.state.gov/j/inl/merida/. Accessed 20 May 2015.

U.S. Trade Representative (2013) Mexico. http://www.ustr.gov/countriesregions/americas/mexico. Accessed 20 May 2015.

\section{TABLES}

Table 1: Mean scores of the three frames in news reports originating from the US, Mexico, and the EU

\begin{tabular}{lcccc}
\hline \multirow{2}{*}{ News frames } & \multicolumn{3}{c}{ Country or region } & Total \\
\cline { 2 - 5 } & $.23(.33)^{*}$ & $.08(.24)^{*}$ & $.18(.30)^{*}$ & $.18(.31)$ \\
\hline Conflict & $.48(.43)^{* * *}$ & $.38(.43)^{* * *}$ & $.16(.32)^{* * *}$ & $.33(.43)$ \\
Economic & $.15(.24)^{* *}$ & $.32(.36)^{* *}$ & $.17(.31)^{* * *}$ & $.20(.30)$ \\
Morality & 105 & 53 & 42 & 200 \\
& $N$ & & & \\
\hline
\end{tabular}


Table 2: Mean scores of the informed actions in news reports originating from the US, Mexico, and the EU

\begin{tabular}{|c|c|c|c|c|}
\hline \multirow{2}{*}{ Strategies/Informed Actions } & \multicolumn{3}{|c|}{ Country or region } & \multirow{2}{*}{ Total } \\
\hline & US & Mexico & $\mathrm{EU}$ & \\
\hline$\overline{\text { AVOID }}$ & $.13(.22)^{* * * *}$ & $.23(.36)^{* * *}$ & $.02(.07)^{* * *}$ & $.13(.26)$ \\
\hline ACQUIESCE & $.16(.32)^{* *}$ & $.22(.37)^{* *}$ & $.37(.38)^{* *}$ & $.22(.35)$ \\
\hline MANIPULATE & $.20(.33)$ & $.16(.32)$ & $.16(.35)$ & $.18(.33)$ \\
\hline $\begin{array}{l}\text { Violence and SME } \\
\text { infrastructure }\end{array}$ & $.24(.31)^{*}$ & $.12(.28)^{*}$ & $.26(.28)^{*}$ & $.21(.30)$ \\
\hline Violence and entrepreneurs & $.67(.34)^{* * *}$ & $.41(.37)^{* * *}$ & $.65(.26)^{* * *}$ & $.60(.35)$ \\
\hline$N$ & 105 & 53 & 42 & 200 \\
\hline
\end{tabular}

